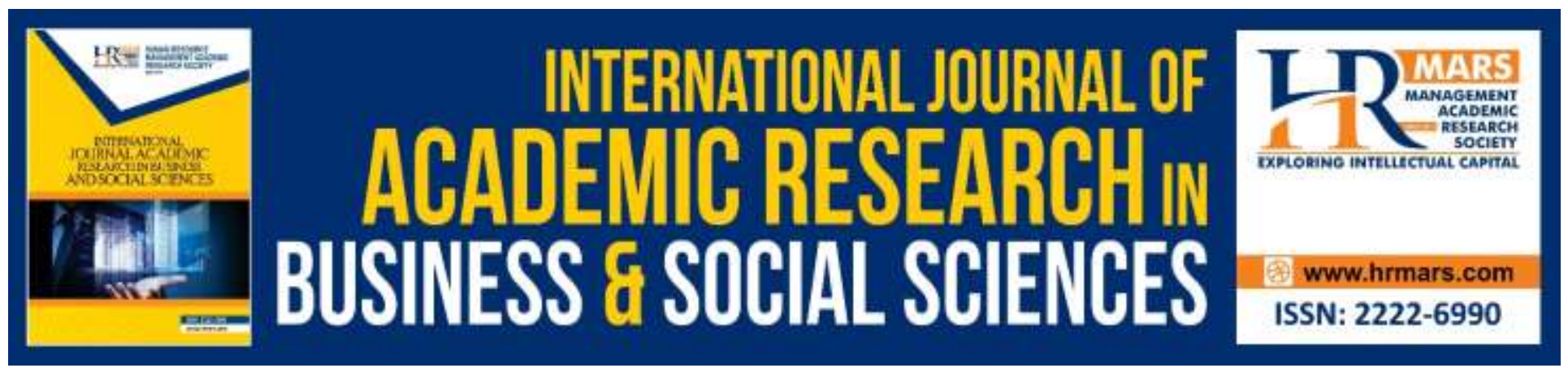

\title{
The Relationship between Intention and Actual Entrepreneurial as a Career Choice of Malaysian Graduate
}

Noorkartina Mohamad and Mai Syaheera M. Shaari

To Link this Article: http://dx.doi.org/10.6007/IJARBSS/v9-i6/6075

DOI: $10.6007 /$ IJARBSS/v9-i6/6075

Received: 15 April 2019, Revised: 19 May 2019, Accepted: 09 June 2019

Published Online: 29 June 2019

In-Text Citation: (Mohamad \& Shaari, 2019)

To Cite this Article: Mohamad, N., \& Shaari, M. S. M. (2019). The Relationship between Intention and Actual Entrepreneurial As A Career Choice of Malaysian Graduate. International Journal of Academic Research in Business and Social Sciences, 9(6), 1140-1146.

Copyright: (C) 2019 The Author(s)

Published by Human Resource Management Academic Research Society (www.hrmars.com)

This article is published under the Creative Commons Attribution (CC BY 4.0) license. Anyone may reproduce, distribute, translate and create derivative works of this article (for both commercial and non-commercial purposes), subject to full attribution to the original publication and authors. The full terms of this license may be seen

at: http://creativecommons.org/licences/by/4.0/legalcode

Vol. 9, No. 6, 2019, Pg. 1140 - 1146

http://hrmars.com/index.php/pages/detail/IJARBSS

JOURNAL HOMEPAGE

Full Terms \& Conditions of access and use can be found at http://hrmars.com/index.php/pages/detail/publication-ethics 


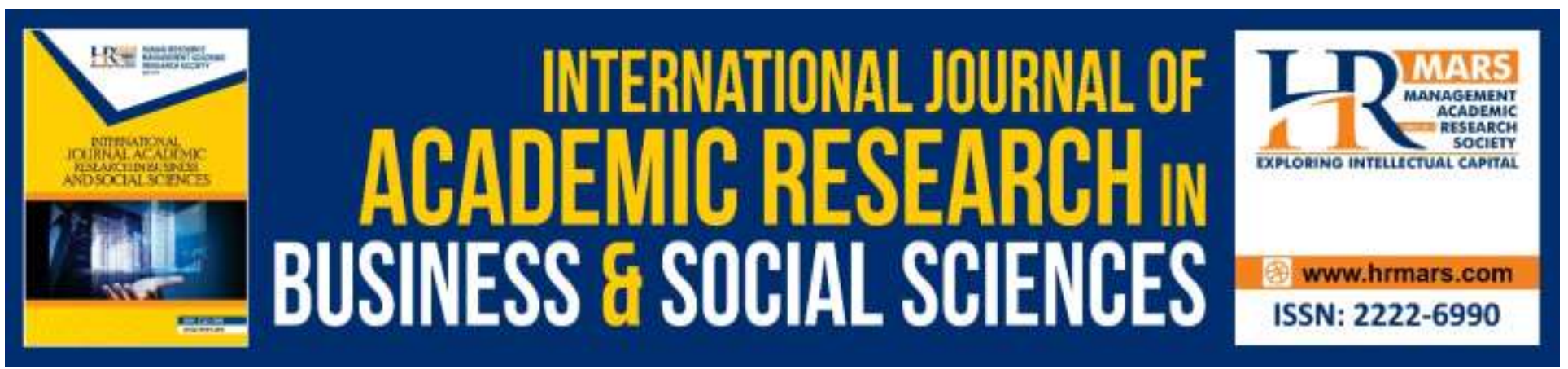

\title{
The Relationship between Intention and Actual Entrepreneurial as a Career Choice of Malaysian Graduate
}

\author{
Noorkartina Mohamad and Mai Syaheera M. Shaari \\ Faculty of Management and Muamalah, Islamic College University of Perlis, Perlis
}

\begin{abstract}
Entrepreneurship has been recognized as a catalyst for the economic growth of a nation and is becoming an important field in Malaysia. Graduates' involvement in entrepreneurial activities is encouraged and the Malaysian government has invested millions of Ringgit in support of this agenda to increase the intention of students to be entrepreneur. However, the statistics showed that, as of 2013, only 1.7 percent of graduates were self-employed, compared to the 5 percent aspired by the government. It is therefore imperative to study the relationship between the intention and actual choice to be graduate entrepreneur. Data analysis using logistics model were carried out with a sample of 2,300 graduates (including those pursuing entrepreneur degrees). Results indicate a significant positive relationship between the graduates' intention to become entrepreneurs and their actual choice of being entrepreneurs. However, some of the intentions are not translated into actual choice. In choosing to become an entrepreneur, having the intention alone may not be enough but it is an important prerequisite. The graduate's actual choice to be entrepreneur is triggered by intention. Although there is a probability for intention to not being translated into actual choice, entrepreneurial intention is required to ensure the actual choice of becoming an entrepreneur. In other words, in choosing to become an entrepreneur, having the intention alone may not be enough but it is definitely an important prerequisite.
\end{abstract}

Keywords: Graduates, Intention, Actual Choice, Entrepreneurship Education, Generic Skills

\section{Introduction}

The intricacies of the labour market have long been acknowledged in the theories of job searching and unemployment (Lim, 2008). Workforces are heterogeneous with respect to their capabilities, preferences, and other aspects, whereas jobs are varied with regards to their requirements and compensation packages (Lim, 2008). In 2013, 22,041 graduates were said to be unemployed, accounting for $34 \%$ of the overall unemployed workforce, according to the Ministry of Education (2014). Furthermore, 30,000 graduates were working in a field, which did not correspond to their higher education credentials (Zaliza \& Mohd Safarin, 2014). Hence, graduates should develop 
alternatives instead of depending on paid employment. An effectual option recommended by experts in economics is self-employment (Aldrich \& Cliff, 2003; and Matlay, 2006). The tendency towards taking up self- employment is highest among the inoperative and second highest among jobless graduates (Anderson \& Wadensjo, 2006). Entrepreneurship (self-employment) can provide a significant volume of output across the world, including in China (Zhengxia et al., 2012) and in Malaysia (Ooi et al., 2011; Ishfaq et al., 2010). As outlined by the Critical Agenda Project (CAP) which fell under the National Higher Education Action Plan Phase 2 (PSPTN, 2011-2015), the government aimed at increasing the entrepreneurship of undergraduates by over $300 \%$ (from $1.6 \%$ to $5 \%$ ). Unfortunately, on average, during the five-year period of 2009-2013, the number of graduates did not reach the desired mark of government despite the enormous resources that invested in the graduate entrepreneur enhancing programs. At the end of 2013 , merely $1.7 \%$ of graduates were selfemployed, thus indicating that only a few fresh graduates had opted for entrepreneurship, which far below the government target of $5 \%$. Relating to the total labour force, according to the statistics for 1982-2008, less than 26 per cent of the working age population were entrepreneurs (Department of Statistics, 2009). It is concluded that the Malaysians are less likely to become entrepreneurs and are more inclined towards working as paid employees (Department of Statistics, 2009). This warrants a study to investigate the entrepreneurial career choice of Malaysia graduates.

Entrepreneurial intention has become one of the most researched topics with regard to graduate entrepreneurship because it is able to provide a prediction of entrepreneurial behaviour (Krueger et al., 2000), complementing the limitations of earlier research where only elements such as personality traits and demographics were utilized to predict behaviour (Nabi et al., 2006). Recent studies have widely incorporated entrepreneurial intention models based on the Theory of Planned Behaviour (TPB) introduced by Ajzen $(1987,1991)$. TPB utilizes intentions to explain an individual's action by confirming a link between attitudes and behaviour (Tariq Ahmed et. al, 2017; Hattab, 2014). The theory is based on how human behaviour can be predicted by understanding the intention towards the behaviour, with the assumption that human behaviour is planned (Izquierdo and Buelens, 2008). It is especially important to use this theory for behaviours that are rare, hard to observe, and involve irregular time lags (Basu and Virick, 2008). The intention to be an entrepreneur might be an important factor to encourage graduates to choose to be entrepreneurs. However, in this context, the participation of graduates in entrepreneurial activities is not a guarantee that they will actually choose to become entrepreneurs. In a similar vein, the factors that influence the intention may be different from the factors that influence the actual choice. Studies on graduate entrepreneurs need to focus not only on the intention, but also on the actual choice made. The problem is that without knowing to what extent intention translates into actual behavior, the effectiveness of entrepreneurship education cannot be determined. Thus, this study investigated to what extent the intention to be an entrepreneur is translated into the actual choice to become an entrepreneur among graduates. 
INTERNATIONAL JOURNAL OF ACADEMIC RESEARCH IN BUSINESS AND SOCIAL SCIENCES

Vol. 9, No. 6, June, 2019, E-ISSN: 2222-6990 @ 2019 HRMARS

\section{Literature Review \\ Intention and Behaviour}

Intention is the single best factor in predicting start-up behaviour and intention models have been utilized by various researchers in explaining the decision to engage in a business (Linan \& RodriguezCohard, 2015; Krueger, et al., 2000; Bird, 1988; Krueger \& Brazeal, 1994; Krueger et al., 2000; Autio et al., 2001; Kolvereid, 1996). In the field of social psychology, planned individual behaviours can be best predicted with intentions, especially if this involves behaviours of an unusual nature, as in they are rare, hard to observe, or involve unpredictable time lags (Krueger et al., 2000). There are several definitions of intention. One of these is a person's willingness to carry out the cognitive description of a behaviour (Ajzen \& Fishbein, 1980). Also, according to Ajzen (1991), intention is a person's willingness to try implementing a behaviour because it contributes towards the actual implementation of the behaviour. As for entrepreneurial intention, Bird (1988) defined it as the state of mind that directs and guides a person's actions towards developing and implementing new business ideas. Attitudes precede intentions, and external factors, such as demographic, traits, education, and situational variables, influence attitudes (Ajzen, 1991; Kolvereid, 1996; Krueger, 2003; Segal et. Al., 2005; Linan \& Chen, 2006; Souitaris et al., 2007), in addition to other factors such as values, needs, habits, wants, and beliefs (Lee \& Wong, 2004) as well as cognitive variables (Ajzen, 1991). Based on the definitions provided, it seems that intention guides a person's willingness to implement a behaviour (Ajzen, 2005; Sheeran, 2002; and Bird, 1988). TPB is one of the most widely used intention models in research (Ajzen, 1988; 1991). The performance of TPB in predicting entrepreneurial intentions is evident in various entrepreneurial-related studies (Bagozzi \& Warshaw, 1990; Autio et al., 2001; Engle et al., 2010; and Wong et al., 2014). In this study, intention is also a decisive factor in predicting the graduates' actual behaviour in pursuing entrepreneurship.

\section{Analysis and Results \\ Sample Characteristics}

The sample comprises 70 percent female and 30 percent male. 84 percent respondents are 20 to 25 years old and only 16 percent respondents are 26 to 30 years old. 64.5 percent of respondents obtained second upper class in their academic achievement. The majority (67.3 percent) of respondents are Malays, followed by Chinese (24.7 percent), Indians (5.6 percent) and other races (2.4 percent). Respondents' employment status, which is divided into unemployed (46 percent), salaried employee (47.2 percent) and self-employed (6.8 percent) and their monthly income. 95.5 percent respondents were non-entrepreneurship degree and only 4.6 percent of respondents were entrepreneurship degree.

\section{Logistics Regression (Choice to be an Entrepreneur)}

A logistic regression was estimated to ascertain the effects of independent variables on the likelihood of the respondents' actual choice to be an entrepreneur. In terms of the goodness of fit, the estimated model was found to be able to correctly predict 93.24 percent (hit-miss evaluation) of the sample respondents. This result presents a higher percentage of correct classification. The pseudo $\mathrm{R}^{2}$ was found to be 0.12 and the overall fit test was significant with a p-value of almost zero. The VIF ranged between 1.07 and 7.58 , which is less than 10 . Thus, the effect of multicollinearity should be 
at its minimum. Regarding the result of marginal effects, Table 3 discuss the effects of the independent variables (which are divided into six sub-categories: formal entrepreneurship education, informal entrepreneurship education, intention to be an entrepreneur, communication apprehension, generic skills and respondents' background) towards respondents' actual choice to be an entrepreneur. The results show that intention (innovation) has significant and positive impact on the choice to be entrepreneur. This positive effect is significant at 1 percent level. This result implies that respondents who have high intention (innovation) are more likely to become an entrepreneur (actual choice of being self-employed). The estimated marginal effect shows that as the intention (innovation) increases one unit, the probability of being entrepreneur will increase by a threepercentage point. Thus, we found that the intention has a high significant and positive impact on choice to be entrepreneur; however, the impact is not enormous. This is consistent with the results of correlation analysis.

\section{Discussion and Conclusion}

The Malaysian government has taken significant actions in order to build up entrepreneurship activities especially among the graduates. Nevertheless, in terms of number of graduates choose to be entrepreneur, the effectiveness of the activities seems not encouraging. The activities could successfully increase the intention to be entrepreneur. The unknown now is to what extend the intention could translate into actual outcome (be entrepreneur)? In order words, what is the relationship between intention and actual choice to be entrepreneur. This paper aims to estimate this relationship. It is found that there is a significant and positive relationship between intention and actual choice; however, the relationship is far below perfect. Thus, the level of tendency for entrepreneurship (low, moderate and high) in graduates could not be underrated. As indicated by Ajzen (1991), a greater intention is a main factor influencing the behaviour of an individual. He added that the greater the faith in a person, which reflects the characteristics and the quality of being desirable in doing something, and their belief in themselves that they possess the basic skills and abilities to work as needed, the higher the possibility that they will act in a distinctive way. In terms of entrepreneurial activities, greater tendencies have been seen to have a higher possibility of materialising in a real start-up (Krueger and Carsrud, 1993). Hence, the university could further enhance the realization of being entrepreneur to add more value for their students by providing academic materials that improve the development of entrepreneurial behaviour and self-efficacy, as these may lead to students becoming entrepreneurs (Zarina et al., 2015). Although intention does not necessarily translate into actual choice, it is needed to ensure the realization of a graduate's actual choice to be an entrepreneur. In short, intention is a necessary condition; it is not solely sufficient for a graduate to be an entrepreneur. Once could conclude that in choosing to become an entrepreneur, having the intention alone may not be enough but it is definitely an important prerequisite.

\section{References}

Ajzen, I. (1987). Attitudes, traits and actions: Dispositional prediction of behaviour in personality and social psychology. Advances in Experimental Social Psychology, 20, 1-63.

Ajzen, I. (1991). "Theory of planned behavior", Organizational Behavior and Human 
INTERNATIONAL JOURNAL OF ACADEMIC RESEARCH IN BUSINESS AND SOCIAL SCIENCES Vol. 9, No. 6, June, 2019, E-ISSN: 2222-6990 @ 2019 HRMARS

Decisions Process, Vol. 50 No. 2, pp. 179-211.

Ajzen, I. (2005). Attitudes, personality and behavior. (2nd ed.). New York: Open University Press.

Ajzen, I., \& Fishbein, M. (1980). Understanding attitudes and predicting social behavior. New Jersey: Prentice Hall.

Autio, E., Keeley, R. H., Klofsten, M., Parker, G. and Hay, M. (2001), “Entrepreneurial intent among students in Scandinavia and in the USA", Enterprise and Innovation Management Studies, Vol. 2 No. 2, pp 145-160.

Autio, E., Keeley, R. H., Klofsten, M. and Ulfdtedt, T. (1997), "Entrepreneurial intent among students: Testing an intent model in Asia, Scandinavia, and USA", Frontier of Entrepreneurship Research, Vol. 17 No. 1, pp. 133-147.

Basu, A., \& Virick, M. (2008). Assessing entrepreneurial intentions amongst students: A comparative study. National Collegiate Inventors \& Innovators Alliance, 1(1), 79-86.

Bird, B. (1988). Implementing entrepreneurial ideas: The case of intention. Academy of Management Review, 13, 442-453.

Engle, R., Dimitriadi, N., Gavidia, J. V., Schlaegel, C., Delanoe, S., Alvarado, I., Wolff, B. (2010). International Journal of Entrepreneurial Behaviour and Research. Entrepreneurial intent: $A$ twelve-country evaluation of Ajzen's model of planned behaviour. 16(1), 36-58.

Hattab, H. (2014). Impact of entrepreneurship education on the entrepreneurial intentions of university students in Egypt. Journal of Entrepreneurship, 23(1), 1-18.

Ishfaq, A., Muhammad Musarrat, N., Zafar, A., Muhammad Zeeshan, S., Ahmad, U., Wasim, R., \& Naveed, A. (2010). Determinants of students' entrepreneurial career intentions: Evidence from business graduates. European Journal of Social Sciences, 15(2), 14-22.

Izquierdo, E., \& Buelens, M. (2008, July). Competing models of entrepreneurial intentions: The influence of self-efficacy and attitudes. Paper presented at Internationalizing Entrepreneurship Education and Training, IntEnT2008 Conference, Oxford, Ohio, USA.

Krueger, N., F. \& Brazeal, D. V. (1994), “Entrepreneurial potential and potential entrepreneurs", Entrepreneurship Theory and Practice, Vol 18 No. 1, pp. 91-104.

Krueger, N., F., \& Carsrud, A., L. (1993). Entrepreneurial intentions: applying the theory of planned behavior. Entrepreneurship \& Regional Development, 5(4), 315- 330.

Krueger, N., F., Micheal, D. R. \& Carsrud, A. L. (2000), “Competing models of entrepreneurial intention", Journal of Business Venturing, Vol 15 No 1, pp. 411-432.

Krueger, N., F., Micheal, D. R., \& Carsrud, A. L. (2000). Competing models of entrepreneurial intention. Journal of Business Venturing, 15(1), 411-432.

Kolvereid, L. (1996), "Prediction of employment status choice intentions", Entrepreneurship Theory and Practice, Vol. 21 No. 1, pp. 47-57.

Lee, S. H. and Wong, P. K. (2004), "An exploratory study of technopreneurial intentions: A career anchor perspective", Journal of Business Venturing, Vol. 19 No. 1, pp. 7-28.

Lim, H. E. (2008). Feasibility of early identification of low employability graduates in Malaysia. Malaysian Journal of Economic Studies, 45(2), 95- 112.

Linan, F., \& Chen, Y. W. (2006). Testing the entrepreneurial intention model on a two-country 
INTERNATIONAL JOURNAL OF ACADEMIC RESEARCH IN BUSINESS AND SOCIAL SCIENCES

Vol. 9, No. 6, June, 2019, E-ISSN: 2222-6990 @ 2019 HRMARS

sample (Document de Treball num. 06/7). Retrieved January 17, 2016, from https://www.researchgate.net/publication/28117836_Testing_the_Entreprene urial_Intention_Model_on_a_Two-Country_Sample

Linan, F., \& Rodríguez-Cohard, J. C. (2015). Assessing the stability of graduates' entrepreneurial intentions and exploring its predictive capacity. Academia Revista Latinoamericana de Administracion, 28(1), pp. 77-98.

Malaysia Department of Statistics. (2009). Siaran khas penyiasatan tenaga buruh usahawan di Malaysia. Retrieved January 17, 2016, from http://www.statistics.gov.my/portal/download_Labour/files/BPTMS/SIARA N_KHAS_(USAHAWAN_DI_MALAYSIA).pdf

Matlay, H. (2006b), "Entrepreneurship education in the UK: A critical perspective", Paper presented at The 29th ISBE National Conference, Cardiff.

Ministry of Finance, Malaysia. (2014). The 2012 Budget. Percetakan Nasional Malaysia Berhad. Kuala Lumpur.

Nabi, G., Holden, R. and Walmsley, A. (2006), "Graduate career-making and business startup: A literature review", Education + Training, Vol. 48 No. 5, pp. 373-385.

Segal, G., Borgia, D., \& Schoenfeld, J. (2005). The motivation to become an entrepreneur. International Journal of Entrepreneurial Behaviour and Research, 11(1), 42-57.

Sheeran, P. (2002), "Intention-behaviour relations: A conceptual and empirical review", European Review of Social Psychology, Vol 12 Vol. 1, pp. 1-36.

Wong, P. K., Ho, Y. P., \& Low, P. C. (2014). Do university entrepreneurship programs influence students' entrepreneurial behavior? An empirical analysis of university students in Singapore. Retrieved January 17, 2016, from Social Science Research Network: http://ssrn.com/abstract=2411266

Zaliza, H., \& Mohd Safarin, N. (2014). Unemployment among Malaysia graduates: Graduates' attributes, lecturers' competency and quality of education. Procedia- Social and Behavioral Sciences, 112, 1056-1063. 